\title{
Lack of association between ACE ID genetic polymorphism and diabetes or hypertension in Brazilians aged from 50 to 70 years old
}

\author{
Falta de associação entre o polimorfismo ID do gene da ECA e diabetes ou hipertensão \\ em brasileiros com idade entre 50 a 70 anos
}

Vitor Nolasco de Moraes $^{1}$, Carlos Roberto Bueno Junior ${ }^{1,2}$

\begin{abstract}
The present study examined the association between ACE ID polymorphism and diabetes or hypertension in individuals aged between 50 to 70 years old. The participants were recruited before initiating a physical training program and divided into groups, according to their genotype of the ACE gene; DD $(n=40)$, ID $(n=55)$, or II $(n=31)$. The anthropometrical characteristics of the participants were evaluated and anamneses performed to establish if the participants presented diabetes and/or hypertension. From the data obtained for anthropometric characteristics, diabetes, and hypertension, we did not find any association with the ACE ID genotypes (DD, ID and II). ACE ID polymorphism may not have an association with diabetes or hypertension in the 50 to 70 years old Brazilian population, but it might have an association in other populations with different ages.
\end{abstract}

Keywords: Chronic Disease. Aging. Health. Genetic Polymorphisms.

\begin{abstract}
RESUMO
O presente trabalho verificou a associação entre o polimorfismo ID do Gene. da ECA e diabetes ou hipertensão em indivíduos de 50 a 70 anos. Os Participantes foram recrutados antes de iniciarem em um programa de atividade física e foram divididos em grupos, de acordo com genótipo para o Gene. da ECA; DD $(n=40)$, ID $(n=55)$, ou II $(n=31)$. Dados antropométricos dos participantes foram coletados, e também responderam uma anamnese afim de estabelecer se possuíam ou não diabetes e/ou hipertensão. Para os dados antropométricos, diabetes e hipertensão, não foi encontrado associação com os genótipos (DD, ID e II) para o Gene. da ECA. O polimorfismo ID do Gene. da ECA pode não ter associação com diabetes ou hipertensão na população de 50 a 70 anos brasileira, mas pode ter associação em indivíduos de outros países e de diferentes idades.
\end{abstract}

Palavras chave: Doença Crônica. Envelhecimento. Saúde. Polimorfismo Genético.

1. Departamento de Clínica Médica, Faculdade de Medicina de Ribeirão Preto, Universidade de São Paulo, Ribeirão Preto, SP, Brasil

2. Escola de Educação Física e Esporte de Ribeirão Preto, Universidade de São Paulo, Ribeirão Preto, SP, Brasil
CORRESPONDÊNCIA:

Carlos Roberto Bueno Junior Escola de Educação Física e Esporte de Ribeirão Preto - USP. Av. Bandeirantes, 3900 - Monte Alegre CEP: 14049-907 Ribeirão Preto/SP. buenojr@usp.br

Recebido em 18/10/2016 Aprovado em 28/03/2017 


\section{Introduction}

Aging is a dynamic, progressive, and irreversible process that forms part of human life. This process is related to biological, social, and psychological declines. ${ }^{1}$ Aging is related to an increase in the prevalence of chronic diseases, such as hypertension and diabetes. These diseases are associated with a worse life quality in older people, and environmental and genetic factors can affect both diseases. $^{2}$

Type 1 diabetes mellitus is a result of immune disorders, and is characterized by destruction of pancreatic islet $\beta$ cells and insulitis, resulting in a deficient in or lack of insulin secretion. ${ }^{3}$ Type 2 diabetes mellitus is characterized by chronic high levels of blood glucose and altered levels of insulin, resulting in insulin resistance or insulin insufficiency in skeletal muscle, the liver, and adipose tissue. ${ }^{4}$ Hypertension is characterized by systolic blood pressure higher than $140 \mathrm{mmHg}$ and/or diastolic blood pressure higher than $90 \mathrm{mmHg}$. The prognosis of these diseases is still unknown, but older age and obesity are the two main risk factors. ${ }^{5}$

The ACE enzyme acts by converting angiotensin I into angiotensin II, which has a vasoconstrictor role. The genetic polymorphism (rs 1799752) in the ACE gene is responsible for an insertion (I allele) or deletion (D allele) of $287 \mathrm{pb},{ }^{6}$ which the $D$ allele results in a higher Gene. expression, and seems to be associated with increased risk for diabetes and hypertension. 7,8 In addition, higher level of ACE in normotensive diabetes-induced mice resulted in increased blood pressure and nephropathy. ${ }^{9}$ To our knowledge, there are few studies, mentioned below in the discussion, regarding the association of the frequency of ACE ID genotype with hypertension and diabetes in older subjects, still further in Brazilian older individuals.

Evaluating the association of ACE ID genotype frequency and chronic diseases in older individuals is important to predict which is associated with these diseases in order to target the relevant portion of the population before they reach old age to improve their life quality and possibly avoid the diseases. In this regard, we aimed to evaluate the association between the ACE ID genetic polymorphism and hypertension or diabetes.

\section{Methods}

\section{Participants}

Older participants aged between 50 to 70 years old, before initiating in an exercise training program were invited to participate in this research. The exclusion criteria of the exercise training program were present cardiovascular disease or risk factors for cardiovascular disease or other diseases without to present medical certificate to physical exercise. The participants signed a written informed consent. The experimental procedure was approved by the Ethics Committee of the Faculty of Philosophy Sciences and Languages of Ribeirão Preto FFCLRP (University of São Paulo USP CAAE: 24579513.4.0000.5407).

\section{Genotype assessment}

A peripheral blood sample was collected in EDTA tubes and the DNA was extracted using the salting out method. ${ }^{10}$ The ACE I/D polymorphisms (rs 1799752) were amplified by the polymerase chain reaction (PCR) and the products from the amplification were genotyped by electrophoresis in agarose gel. The primers used were F-5'CTGGAGACCACTCCCATCCTTTCT-3' and R-5'GATCTGGCCATCACATTCGTCAGAT-3'. The PCR conditions were: initial denaturation at $95^{\circ} \mathrm{C}$ for $3 \mathrm{~min}$, 35 cycles at $95^{\circ} \mathrm{C}$ for $30 \mathrm{~s}, 58^{\circ} \mathrm{C}$ for $30 \mathrm{~s}, 72^{\circ} \mathrm{C}$ for $30 \mathrm{~s}$, and a final extension at $72^{\circ} \mathrm{C}$ for $10 \mathrm{~min}$. The fragments with the insertion (allele I) of $287 \mathrm{pb}$ result in an amplicon of $478 \mathrm{bp}$, and the fragments without the insertion (allele $D$ ) result in an amplicon of $191 \mathrm{pb}$. Fragments were detected on $1.5 \%$ agarose gel containing ethidium bromide. ${ }^{11,12}$

\section{Measurements}

Participants were evaluated for the following parameters: body mass (precision $50 \mathrm{~g}$ ), and height using a stadiometer (precision $1.0 \mathrm{~mm}$ ) (Welmy W200LCD), and body mass index - BMI (weight divided by height squared). ${ }^{13}$ In addition, an anamnesis was performed to establish if the participants presented diabetes or hypertension. We also applied the International Physical Activity Questionnaire (IPAQ). ${ }^{14}$ All data were collected in the initial evaluation of the training program. 


\section{Statistical analyses}

Individuals were divided into groups according to their genotype. The data were analyzed by one-way ANOVA. Bonferroni's post hoc test was used for ANOVA differences. For the qualitative analyses, the chi-square test was used. The HardyWeinberg Equilibrium was calculated using the $\chi^{2}$ test. The adopted significance level was $p \leq 0.05$. The data were analyzed using SPSS 21.0.

\section{Results}

The genotype distribution for the ACE gene was DD $n=40(31.75 \%)$, ID $n=55(43.65 \%)$, and II $n=31(24.60 \%)$. No significant differences was observed in the Hardy-Weinberg Equilibrium $(p=0.169)$.
The data for age, height, weight, and BMI are presented in table 1 . There were no differences between the groups for these variables. Table 2 presents data on the relationship between diabetes, hypertension, and the ACE genotypes. No association between the ACE genotypes and diabetes or hypertension was found.

\section{Discussion}

In the present study, we aimed to investigate the association between the ACE ID genotypes and diabetes or hypertension.

Table 1 presents the anthropometrical characteristics. No association was found with the ACE ID genotypes. Pereira et al., ${ }^{15}$ in a study with 139 older Caucasian women, 65.5 (8.2) years, did not find differences between the genotypes for weight

Table 1: Sample characterization

\begin{tabular}{lccr}
\hline & II & ID & DD \\
& $\mathrm{N}=40$ & $\mathrm{~N}=55$ & $\mathrm{~N}=31$ \\
\hline Age (years) & $61.26(6.25)$ & $60.60(5.46)$ & $60.00(5.25)$ \\
Height (m) & $1.60(0.08)$ & $1.61(0.07)$ & $1.60(0.05)$ \\
Weight (kg) & $77.30(17.69)$ & $75.51(18.32)$ & $71.56(11.50)$ \\
BMI (kg/m ${ }^{2}$ ) & $30.45(6.34)$ & $28.98(6.40)$ & $27.88(4.17)$ \\
Walking (min/week) & $180.4(194.8)$ & $193.5(176.1)$ & $186.2(187.0)$ \\
Moderate PA (min/week) & $236.4(337.0)$ & $379.0(527.4)$ & $382.9(455.6)$ \\
Intense PA (min/week) & $61.0(198.5)$ & $97.9(244.2)$ & $32.9(73.6)$ \\
\hline
\end{tabular}

Data are presented as mean and standard deviation in parentheses; BMI: body mass index.

PA: Physical activity

Table 2: Association between diabetes, hypertension and ACE genotypes

\begin{tabular}{|c|c|c|c|c|c|c|}
\hline & \multicolumn{3}{|c|}{ Diabetes } & \multicolumn{3}{|c|}{ Hypertension } \\
\hline & Yes & No & $P$ & Yes & No & $\mathrm{P}$ \\
\hline DD $N=40$ & $85 \%$ & $15 \%$ & & $52.5 \%$ & $47.5 \%$ & \\
\hline ID $N=54$ & $79.6 \%$ & $20.4 \%$ & 0.350 & $48.1 \%$ & $51.9 \%$ & 0.341 \\
\hline II $\mathbf{N}=\mathbf{3 1}$ & $71.0 \%$ & $29.0 \%$ & & $64.5 \%$ & $35.5 \%$ & \\
\hline
\end{tabular}

Data are presented as number of participants in percentage that have or do not diabetes or hypertension according to their genotype. 
or BMI. Keogh et al., ${ }^{16}$ in a study with Australian older woman, 69.8 (4.9) years, did not observe any differences for weight or BMI between the groups. Lemes et al., ${ }^{17}$ in a study with Brazilian children and adolescents between the ages of 7 and 16 years did not find any association between weight and the genotypes, however the authors observed an association of $D$ allele with higher BMI values for boys. $\mathrm{Kim}^{18}$ demonstrated that Korean adult women aged 38.0 (1.0) years, presented no association between the ACE genotypes and anthropometric characteristics. Thus, the ACE ID genotype seems not to be associated with anthropometric characteristics in older adults or adults, although it may have an association in children. In addition, our data show that the groups in the present study were similar, suggesting that anthropometric characteristics did not affect the condition of the groups for diabetes or hypertension.

With regard to diabetes and hypertension, we did not find any association between the ACE genotypes and hypertension or diabetes, as demonstrated in Table 2. The ACE enzyme is responsible for converting angiotensin I into angiotensin II, which is a potent vasoconstrictor. In addition, it seems to be related to diabetes as angiotensin II is an inflammatory adipocytokine and an increase in the enzyme activity results in glucose storage. ${ }^{19}$

Shaikh et al., ${ }^{20}$ in a study with 110 healthy participants and 115 with diabetes mellitus demonstrated a higher $D$ allele frequency in the group with diabetes when compared to the control. Baroudi et al., ${ }^{21}$ studying the association between the ACE ID genotype and type 2 diabetes in older Jerbian individuals, demonstrated a higher DD genotype frequency in the diabetes group than the control group. On the other hand, Wollinger et al., ${ }^{22}$ researching the older Brazilian population, demonstrated a lack of association between the ACE genotypes and type 2 diabetes.

Related to hypertension, Shanmuganathan et al., ${ }^{23}$ demonstrated an association between the ACE genotypes and hypertension in the Indian Population. In the above previously mentioned study, $\mathrm{Kim}^{16}$ found only a trend for the association between hypertension and ACE genotypes. In contrast, Arfa et al., ${ }^{24}$ in a study with Tunisian subjects, did not found any association between hypertension and ACE genotypes.
As a limitation of the present study, we can mention the evaluation of the presence or not of diabetes and/or hypertension only through anamneses, which may result in diagnosis mistakes. There is a possibility that some participants did not know about their clinical diagnosis. However, all participants were evaluated by a doctor prior to the study, which should have helped to avoid errors due to misdiagnosis.

Furthermore, to utilize other methods in the evaluation would have resulted in fewer participants in the study due to the use of invasive methods. In addition, as a further limitation, the expression level of ACE was not evaluated which could have increased the impact of our results.

\section{Conclusion}

In conclusion, this research demonstrated that there might not be any association between the ACE genotypes and diabetes and hypertension in the older Brazilian population. However, our results are different from others in the literature with different ethnical groups. Thus, further studies are necessary to reach a conclusion about the relationship between ACE ID genotypes and diabetes and hypertension.

\section{Acknowledgments}

We would thank you the Sao Paulo Research Foundation (FAPESP - process 2013/21159-8) and CNPq (process 485045/2013-3) to have supported this research by grants.

\section{References}

1. Litvoc J, Brito FCD. Envelhecimento, Prevenção e Promoção da Saúde São Paulo, Brasil: Atheneu 2004; 1-16.

2. Lebrã ML. Epidemiologia do envelhecimento. BIS, Bol Inst Saúde. 2009; 47: 23-6.

3. Vanikar AV, Trivedi HL, Thakkar UG. Stem cell therapy emerging as the key player in treating type 1 diabetes mellitus. Cytotherapy. 2016; 18: 1077-86.

4. Aly YE, Abdou AS, Rashad MM, Nassef MM. Effect of exercise on serum vitamin $D$ and tissue vitamin $D$ receptors in experimentally induced type 2 Diabetes Mellitus. J Adv Res. 2016;7:671-9.

5. Calhoun DA, Jones D, Textor S, Goff DC, Murphy TP, Toto $R D$, et al. Resistant hypertension: diagnosis, evaluation, and treatment a scientific statement from the American Heart Association Professional Education Committee of the Council for High Blood Pressure Research. Hypertens. 2008; 51: 1403-1419. 
6. Zhang B, Tanaka H, Shono N, Miura S, Kiyonaga A, Shindo $M$, et al. The I allele of the angiotensinconverting enzyme Gene. is associated with an increased percentage of slowtwitch type I fibers in human skeletal muscle. Clin Genet. 2003; 63: 139-44.

7. Stephens JW ${ }^{1}$, Dhamrait SS, Cooper JA, Acharya J , Miller GJ, Hurel SJ, Humphries SE. The D allele of the ACE I/D common Gene. variant is associated with Type 2 diabetes mellitus in Caucasian subjects. Mol Genet Metab. 2005; 84: 83-9.

8. Zarouk WA, Hussein IR, Esmaeil NN, Raslan HM, Reheim $\mathrm{HA}$, Moguib $\mathrm{O}$ et al. Association of angiotensin converting enzyme Gene. (I/D) polymorphism with hypertension and type 2 diabetes. Bratisl Lek Listy. 2012; 13: 14-18.

9. Huang W, Gallois Y, Bouby N, Bruneval P, Heudes D, Belair MF et al. Genetically increased angiotensin I-converting enzyme level and renal complications in the diabetic mouse. Proc Natl Acad Sci U. S. A. 2001, 98: 13330-4.

10. Noguera NI, Tallano CE, Bragós IM, Milani AC. Modified salting out method for DNA isolation from newborn cord blood nucleated cells. J Clin Lab Anal. 2000; 14: 280-3.

11. Gómez-Gallego F, Santiago C, Gonzalez-Freire M, Muniesa CA, Del Valle MF, Perez M. et al. Endurance performance: genes or Gene. combinations? Int J Sports Med. 2009; 30: 66-72.

12. Lima RM, Leite TKM, Pereira RW, Rabelo HT, Roth SM, Oliveira RJ. ACE and ACTN3 genotypes in older women: muscular phenotypes. Int J Sports Med. 2011; 32: 66.

13. Gomes T, Tibana TRA, Nascimento DDC, Silva RAS, Almeida JA, Balsamo S, Voltarelli FA, Prestes J. Qualidade de vida e síndrome metabólica e mulheres brasileiras: análise da correlação com a aptidão aeróbia e a força muscular. Motricidade. 2015; 11:48-61.

14. Matsudo $\mathrm{S}$, Araújo $\mathrm{T}$, Marsudo $\mathrm{V}$, Andrade $\mathrm{D}$, Andrade $\mathrm{E}$, Braggion G. Questinário internacional de atividade física (IPAQ): estudo de validade e reprodutibilidade no Brasil. Rev Bras Ativ Fís Saúde. 2001; 6:5-18.

15. Pereira $A$, Costa $A M$, Izquierdo $M$, Silva $A J$, Bastos $E$, Marques MC. ACE I/D and ACTN3 R/X polymorphisms as potential factors in modulating exercise-related phenotypes in older women in response to a muscle power training stimuli. Age (Dordr). 2013; 35: 1949-59.
16. Keogh JW, Palmer BR, Taylor D, Kilding AE. ACE and UCP2 Gene. 18 polymorphisms and their association with baseline and exercise-related changes in the 19 functional performance of older adults. PeerJ. 2015; 3: e980.

17. Lemes VA, Neves AL, Guazzelli IC, Frazzatto E, Nicolau C, Corrêa-Giannella ML et al. Angiotensin converting enzyme insertion/deletion polymorphism is associated with increased adiposity and blood pressure in obese children and adolescents. Gene. 2013; 532:197-202.

18. Kim K. Association of angiotensin-converting enzyme insertion/deletion polymorphism with obesity, cardiovascular risk factors and exercise-mediated changes in Korean women. Eur J Appl Physiol 2009; 105: 879-87.

19. Ramalingam L, Menikdewella K, LeMieux M, Dufour JM, Kaur $\mathrm{G}$, Kalupahana $\mathrm{N}$, et al. The renin angiotensin system, oxidative stress and mitochondrial function in obesity and insulin resistance. Biochim. Biophys. Acta. 2016 http://dx.doi.org/10.1016/j.bbadis.2016.07.019

20. Shaikh R, Shahid SM, Mansoor Q, Ismail M, Azhar A. Genetic variants of ACE (Insertion/Deletion) and AGT (M268T) genes in patients with diabetes and nephropathy. J Renin Angiotensin Aldosterone Syst. 2014; 15: 124-30.

21. Baroudi T, Bouhaha R, Moran-Moguel C, Sanchez-Corona J, Maiz HB, Abid HK et al. Association of the insertion/ deletion polymorphism of the angiotensin-converting enzyme Gene. with type 2 diabetes in two ethnic groups of Jerba Island in Tunisia. J Renin Angiotensin Aldosterone Syst. 2009; 10: 35-40.

22. Wollinger LM, Dal Bosco SM, Rempel C, Almeida SEM, Berlese DB, Castoldi RP et al. Role of ACE and AGT Gene. polymorphisms in genetic susceptibility to diabetes mellitus type 2 in a Brazilian sample. Genet Mol Res. 2015; 14: $19110-16$

23. Shanmuganathan, R., Kumaresan, R., \& Giri, P. Prevalence of angiotensin converting enzyme (ACE) Gene. insertion/deletion polymorphism in South Indian population with hypertension and chronic kidney disease. J Postgrad Med. 2015; 61: 230.

24. Arfa I, Nouira S, Abid A, Bouafif-Ben AN, Zorgati MM, Malouche $D$, et al. Lack of association between renin-angiotensin system (RAS) polymorphisms and hypertension in Tunisian type 2 diabetics. Tunis Med 2010; 88: 38-41. 